\title{
Expansion of global sea cucumber fisheries buoys exports
}

\author{
Chantal Conand ${ }^{1,2}$ \\ 1. Université de La Réunion, ENTROPIE, 97715 Saint Denis messag, La Réunion; conand@univ-reunion.fr \\ 2. Muséum National Histoire Naturelle Paris, rue Cuvier, 75005 Paris, France
}

Recibido 07-VII-2016. Corregido 25-II-2017. Aceptado 23-VI-2017.

\begin{abstract}
The sea cucumber fisheries have expanded during the past two decades, at a faster rate than the management capacity. The exploitation is now qualified as 'serial' and 'contagious'. I present the most recent trends from the last six years of the FAO capture data. Hong Kong remains the most important market for the imports and re-exports of the processed products, mainly the dry "trepang" (or bêche-de-mer), but also other product forms, which raised difficulties for the analysis. The catches still increase. with new countries developing export fisheries, species targeted change and new products are traded. Rev. Biol. Trop. 65(Suppl. 1): S1-S10. Epub 2017 November 01.
\end{abstract}

Key words: holothurian; trepang; bêche-de-mer; statistics; trade; globalization; management.

Several sea cucumbers species (Echinodermata: Holothuroidea) are consumed traditionally, mostly by asiatic populations and their fisheries have been presented in detail (Conand, 1990, 1998, 2004, 2006; Conand \& Byrne, 1993). For the Chinese consumption the holothurians are mostly processed in a dry product called Hai Shen, trepang or bêche-demer, depending on the region where they are fished. Foreign fisheries have been limited to the Indo-Pacific for a long time.

Given the development of China, an increase of demand for trepang occured during the $20^{\text {th }}$ century, making the exploitation very valuable. It remained small scale fisheries (SSF) in most tropical countries, with fishers collecting the commercial species in shallow waters. The processing, traditionally artisanal, comprises several steps (Conand, 1990; Purcell, 2014a) to get a dry product of good quality; it is essential to get a good grade and therefore a good value. The dried products are then shipped to the main markets of Hong Kong, mainland China, Singapore, Taiwan (Conand, 1990; Conand \& Byrne, 1993) and
'China Towns' in the large cities worldwide (Conand, 2015). The product now fetches high prices; for example, in Hong Kong the maximum price per $\mathrm{kg}$ exceeded 1000 US\$ (Purcell, 2014b).

The fisheries have expanded rapidly during the last decades (Conand, 2004; Anderson Flemming, Watson \& Lotze, 2011; Purcell et al., 2013; Eriksson, Conand, Lovatelli, Muthiga, Purcell, 2015a; Fabinyi, 2016) from tropical Indo-Pacific countries where they are multispecific to worldwide tropical regions, as shown in the Latino-America where Isostichopus fuscus is the most valuable species, then to the temperate coastal regions and the overexploitation has become apparent.

Much attention is presently being paid to the fisheries management with an abundant recent literature (for example Friedmann, Purcell, Bell \& Hair, 2008; FAO, 2010; Purcell, 2010; Purcell, et al., 2013, 2014; Eriksson, et al., 2015a; Conand, 2016). The management had first been questioned by FAO at the world scale, with publications and several international meetings, where regional syntheses were 
prepared (Conand, 1990; Lovatelli, et al. 2004; Toral-Granda, Lovatelli \& Vasconcellos, 2008; FAO, 2010; Purcell, 2010). A first version of a book on commercially important sea cucumbers provides detailed informations on taxonomy, biology and distribution of 58 species (Purcell, Samyn \& Conand, 2012a).

The question of CITES listing has first been deeply debated during an international meeting on holothuroids in Malaysia (Conand, 2004; Bruckner, 2006). It is still up-to-date, as shown by the results of the last CITES meeting in South Africa (2016) where the proposed holothuroids were not adopted for listing and the need for more discussions and agreements is still necessary, before adding species. Presently only Isostichopus fuscus from Ecuador is listed in Annex III. A good step forward would be to propose the teatfish group (Holothuria (Microthele) for listing, as the four species H. nobilis, H. whitmaei, $H$. fuscogilva, $H$. sp. 'pentard', presented in Purcell, et al. (2012a), are commercially very valuable large species, easy to recognize, alive as well as processed, a very important point for checking the trade and are largely overfished.

The IUCN listing has followed an international meeting in Colombia (Conand, et al., 2014a; Purcell, et al., 2014). It is effective for sixteen holothurian species with seven endangered and nine vulnerable (see http://www. iucnredlist.org/documents/RedListGuidelines. pdf). For Latin America only one species Isostichopus fuscus is listed as Endangered.

Given the differences in exploited species and in policies the regional scale has appeared the best to facilitate management. The Secretariat of Pacific Community (SPC) has been active on the topic with meetings and a specific journal, the SPC Bêche-de-mer Bulletin published yearly since 1990, giving the main findings and informations on the subject (see http://www.spc.int/coastfish/en/publications/ bulletins/beche-de-mer.html).

Regional meetings (Sea Cucumber Ecosystem Approach Management, SCEAM) have been organized by FAO and other organizations in the tropical Pacific (FAO, 2012) and Indian
Ocean (FAO, 2013). Other important regional projects and initiatives have come from the Australian Centre for International Agricultural Research (ACIAR), the Western Indian Ocean Marine Science Association (WIOMSA), with many publications and syntheses (Conand \& Muthiga, 2007; Friedmann, et al, 2008; Muthiga \& Conand, 2014; Eriksson, et al., 2015b).

Recent fisheries have also developed rapidly in the temperate and tropical parts of the Atlantic (Toral-Granda, Hamel and Mercier in Toral-Granda et al., 2008); several meetings were then organized in Cuba (2014), Mexico (2015) and regionally (Flores et al., 2016). Finally, the fisheries are developing in the Mediterranean sea (González-Wangüemert, Aydin \& Conand,2014; González-Wangüemert, Valente, Henriques, Domínguez-Godino \& Serrão 2016). Noteworthy is the present development of the interest for the biochemical use of the saponines and other components from holothurians (Honey-Escandon, Arreguín-Espinosa, Solís-Marín \& Samyn, 2015; Gomes, Freitas, Duarte \& Rocha-Santos, 2016).

It is therefore necessary to follow the most recent trends in captures and markets, at the different scales, international, regional and in the main producing countries. This will help enabling better decisions and management practices.

\section{MATERIALS AND METHODS}

The FAO capture data of holothurians, by country, for the last six years (FAO, 2009 to 2014) have been analyzed to be able calculate the mean tonnage ( $\mathrm{t}$ p.a.) over this period for the main fishing areas (FAO zones). The data have been separated into two categories:

1. the traditional dry products bêche-de-mer (or trepang) whose processing results in a product weighing only 5 to $8 \%$ of the fresh weight.

2. the other products, frozen and in brine, whose weights do not differ too much from the fresh one. The data for the regions where they appear mostly as other 
products, are transformed into comparable dry weight, by taking $8 \%$ of the values which is a mean reduction coefficient during processing, despite it varies between the species (Conand, 1979, 1990; Purcell, et al., 2009, 2014a, 2016; Purcell, Hair \& Mills, 2012b; Prescott, Zhou \& Prasetyo, 2015). They are then compared with previous results.

Hong Kong statistics for holothurians comprise several categories (Table 1), with overall quantities in $\mathrm{kg}$, for imports and reexports under the following codes:

- 1190 , fresh product for local consumption,

- 1910, frozen product from fresh or processed,

- 1990 , dry or in brine.

The tonnages from the different categories cannot be summed, as the weights they represent, in comparison with the live animal weights, are different.

The category 1990 (dry or in brine) is then used here, in more details, to follow the countries of origin then ranked by percent of the total for the years 2013 and 2014.

These data (2013 and 2014) are presented and analyzed here. The results are then compared with previous results on this market (Conand, 1990; Conand \& Byrne, 1993; Anderson, et al., 2011; To \& Shea, 2012; Conand Shea \& To, 2014b; Eriksson, et al., 2015b).

\section{RESULTS}

World holothurian fisheries: The world catches are presented by FAO regions, from the mean, calculated for the six years period 2009 to 2014 , for the two main categories already defined in previous section (Table 2).

The most important fishing areas are clearly the Western Central Pacific (FAO zone 71) with $6675 \mathrm{t}$ p.a and the Western Indian Ocean (51) with 4179 t p.a.

The main countries by FAO zone for the dry product category (1) are: for the Western Central Pacific (71): Indonesia followed by the Philippines, the Eastern Indian Ocean (57) again Indonesia, the Western Indian Ocean (51) Madagascar, the Pacific Eastern Central (Mexico). Using the transformed weights for the category (2), the main countries are: for the Pacific Northwest (61): Japan, the Atlantic Northwest (21): Canada, the Atlantic Northeast (27): Iceland.

Some important changes over time appear when comparing these results with previous publications (Conand \& Byrne, 1993; Conand, 2004, 2006, 2008; Purcell, et al., 2013).

1. The catches have increased globally, despite overexploitation is mentioned by many observers. It is also possible that they are now better reported than previously.

2. The catches have much increased in temperate regions where the activity is more recent that the traditional tropical fisheries

TABLE 1

Hong Kong categories of sea cucumber products and recent statistics

CUADRO 1

Categorías de Hong Kong de productos de pepino de mar y estadísticas recientes

\begin{tabular}{lcccrr}
\multicolumn{1}{c}{ HK categories } & codes & \multicolumn{2}{c}{ IMPORTS kg } & \multicolumn{2}{c}{ RE-EXPORTS kg } \\
& & 2013 & 2014 & 2013 & 2014 \\
Live, fresh, chilled & 03081190 & 89996 & 108404 & 9240 & 3138295 \\
Frozen, fresh or smoked & 03081910 & 3963866 & 3261949 & 3261011 & 4761700 \\
Dried, salted, in brine & 03081990 & 4941709 & 4427520 & 4563166 & 7899995 \\
& Total & 8995571 & 7797873 & 7833417 & 20484 \\
Prepared foodstuff & 16056100 & 47284 & 24451 & - & \\
\hline
\end{tabular}


TABLE 2

Sea cucumber captures annual tonnage (t) mean for the period 2009 to 2014, by country and FAO fishing areas. The means are presented from FAO yearly statistics (1) and corrected in equivalent dry weights (2) when the data are in fresh weight $(*)$, using $8 \%$ of fresh weight, as correction for weight loss during processing

\section{CUADRO 2}

Tonelaje de captura anual de pepino de mar (t) para el período 2009-2014, por país y por las zonas de pesca de la FAO. Las medias se presentan a partir de las estadísticas anuales de la FAO (1) y se corrigen en pesos secos equivalentes (2) cuando los datos están en peso fresco $(*)$, utilizando el $8 \%$ del peso fresco como corrección para la pérdida de peso durante el procesamiento

\begin{tabular}{|c|c|c|c|}
\hline FISHING AREA Country & code & (1) t mean p.a & (2) t dry p.a \\
\hline PACIFIC NORTH WEST & 61 & $12590^{*}$ & 1008 \\
\hline Japan & & 10073 & \\
\hline Korea, Republic of & & 2517 & \\
\hline ATLANTIC NORTH WEST & 21 & $5859 *$ & 472 \\
\hline Canada & & 5006 & \\
\hline United States of America & & 854 & \\
\hline ATLANTIC NORTH EAST & 27 & $1624 *$ & 128 \\
\hline Iceland & & 1624 & \\
\hline Spain & & & \\
\hline ATLANTIC CENTRAL WEST & 31 & $2669^{*}$ & 216 \\
\hline Bahamas & & 9 & \\
\hline Belize & & 202 & \\
\hline Haiti & & 13 & \\
\hline Honduras & & 686 & \\
\hline Mexico & & 1144 & \\
\hline Nicaragua & & 613 & \\
\hline United States of America & & 1 & \\
\hline Mauritania Atlantic Eastern Central & 34 & 18 & \\
\hline Spain Mediterranean & 37 & 2 & \\
\hline INDIAN OCEAN WEST & 51 & 1555 & 1555 \\
\hline Egypt & & 3 & \\
\hline Kenya & & 31 & \\
\hline Madagascar & & 1336 & \\
\hline Maldives & & 131 & \\
\hline Mauritius & & 33 & \\
\hline Mozambique & & 0 & \\
\hline Tanzania, United Rep. of & & 0 & \\
\hline Yemen & & 20 & \\
\hline INDIAN OCEAN EAST & 57 & 4179 & 4179 \\
\hline Indonesia & & 484 & \\
\hline Malaysia & & - & \\
\hline Sri Lanka & & 3695 & \\
\hline
\end{tabular}


TABLE 2 (Continued)

\begin{tabular}{|c|c|c|c|}
\hline FISHING AREA Country & code & (1) t mean p.a & (2) t dry p.a \\
\hline PACIFIC NORTH-EAST & 67 & $1632 *$ & 128 \\
\hline Canada & & 910 & \\
\hline United States of America & & 722 & \\
\hline PACIFIC CENTRAL WEST & 71 & 6675 & 6675 \\
\hline Cambodia & & 0 & \\
\hline Fiji, Republic of & & 75 & \\
\hline Indonesia & & 5003 & \\
\hline Kiribati & & 75 & \\
\hline Malaysia & & 0 & \\
\hline New Caledonia & & 368 & \\
\hline Palau & & 0 & \\
\hline Papua New Guinea & & 96 & \\
\hline Philippines & & 844 & \\
\hline Solomon Islands & & 199 & \\
\hline Vanuatu & & 1 & \\
\hline Wallis and Futuna Is. & & 16 & \\
\hline PACIFIC CENTRAL EAST & 77 & 935 & 935 \\
\hline French Polynesia & & 178 & \\
\hline Mexico & & 306 & \\
\hline Nicaragua & & 85 & \\
\hline Tonga & & 127 & \\
\hline United States of America & & 238 & \\
\hline New Zealand Pacific Southwest & 81 & 17 & \\
\hline PACIFIC SOUTH EAST & 87 & 182 & 182 \\
\hline Chile & & 182 & \\
\hline Ecuador & & - & \\
\hline
\end{tabular}

(Hamel \& Mercier in Toral-Granda, et al., 2008; Purcell, et al., 2012b).

3. New countries presently exploit the holothurians in the temperate Atlantic and the Mediterranean (González-Wangüemert, et al., 2014, 2016).

Main sea cucumber markets: Several earlier studies have been published on the main markets: Hong Kong, Singapore, and Taiwan (Conand, 1989, 2001, 2004; Conand \& Byrne 1993; Lovatelli, et al., 2004). The reciprocal exchanges between these markets have also been noted, showing that some products can arrive to an intermediate market, before going to the final one (Jaquemet \& Conand 1999). The importance of Hong Kong market for sea cucumber is detailed elsewhere (To \& Shea 2012; Conand, et al., 2014).

Recent publications have analysed Hong Kong statistics, attracting much interest and showing the 'serial exploitation' and spatial extension of the fisheries for holothurians from 1950 to 2006 (Anderson, et al., 2011) and more recently the 'contagious exploitation' showing, from data 1996 to 2011, the 'fast moving system resembling an epidemic disease, where long-distance transport expedites 
large-scale expansion followed by diffusive local spread into neighbouring areas' (Eriksson, et al., 2015b).

From the most recent data (2013 and 2014) presented here for Hong Kong, it appears that:

1. the imports have globally declined, but the weight units in the different categories are questionable;

2. the imports of live, fresh, chilled (code1190), intended for local consumption (as there are nearly no re-exports) have slightly increased;

3. the imports of frozen, fresh or smoked (code 1910) are very important, with more than 3000 t each year, with a small, probably not significant, decrease in 2014; they are mostly re-exported;

4. the dried, salted in brine (code 1990) are even more important than the previous category, with more than 4000 t each year; they are also mostly re-exported.

For this category (code 1990), the details by country, taking into account the countries contributing to at least $1 \%$ of the total, are presented in Table 3, with the ranks for the most important countries, which helps to observe the short term changes:

a. the number of countries still increases, from 29 countries in 2013 to 33 in 2014 ; this is in agreement with previous studies on this essential market.

b. Japan and Indonesia respectively keep the first and second rank.

c. some changes are noted between 2013 and 2014: the Philippines declined, while Mexico and China increased. The Solomons do not appear in 2014.

d. a new category concerns the prepared foodstuff (Table 1), which was not included in previous data, but the product is probably re-exported; more details are needed on this category.
TABLE 3

Hong Kong main imports for 2013 and 2014 for sea cucumbers in category 1990 , by countries with percentage and rank

\section{CUADRO 3}

Principales importaciones de Hong Kong para 2013 y 2014 para los pepinos de mar de la categoría 1990 por países con porcentaje y rango

\begin{tabular}{|c|c|c|c|c|}
\hline \multirow{3}{*}{ Countries } & \multicolumn{2}{|c|}{2013} & \multicolumn{2}{|c|}{2014} \\
\hline & \multicolumn{2}{|c|}{ Total $4941 \mathrm{t}$} & \multicolumn{2}{|c|}{ Total $4427 \mathrm{t}$} \\
\hline & $\%$ & rank & $\%$ & rank \\
\hline US & 6 & 6 & 6 & 5 \\
\hline Aust \& Oceanian Nes & 1 & & 1 & \\
\hline Australia & 2 & & 2 & \\
\hline Canada & 2 & & 2 & \\
\hline Colombia & - & & 1 & \\
\hline Egypt & 1 & & - & \\
\hline Fiji & 7 & 4 & 6 & 5 \\
\hline Greece & 1 & & 3 & \\
\hline Honduras & & & 1 & \\
\hline Indonesia & 10 & 2 & 10 & 2 \\
\hline Japan & 12 & 1 & 11 & 1 \\
\hline S. Korea & 1 & & 1 & \\
\hline Madagascar & 6 & 6 & 6 & 5 \\
\hline Malaysia & 1 & & 1 & \\
\hline Maldives & 1 & & 1 & \\
\hline Mauritania & 1 & & 1 & \\
\hline Mexico & 6 & 6 & 7 & 3 \\
\hline MicronFS-Palau & & & 1 & \\
\hline Mozambique & - & & 1 & \\
\hline New Zealand & - & & 1 & \\
\hline Nicaragua & - & & 2 & \\
\hline Peru & 2 & & 4 & \\
\hline Philippines & 8 & 3 & 5 & 8 \\
\hline Russian & 2 & & 1 & \\
\hline Seychelles & 1 & & 2 & \\
\hline Singapore & 2 & & 1 & \\
\hline Solomon Island & 7 & 4 & - & \\
\hline Sri Lanka & 4 & & 2 & \\
\hline Taiwan & 3 & & 3 & \\
\hline Tanzania & 1 & & 1 & \\
\hline Thailand & 1 & & 1 & \\
\hline The Mainland China & 1 & & 7 & 3 \\
\hline Tonga & 2 & & 1 & \\
\hline Turkey & 1 & & 1 & \\
\hline Yemen & 4 & & 3 & \\
\hline & $>28$ & & $>32$ & \\
\hline
\end{tabular}




\section{DISCUSSION}

These recent statistics on captures have not been examined in detail before this study; previous publications had used FAO data, results from regional meetings, or direct enquires to the fishing countries (Conand, 2004, 2008; Anderson, et al., 2011; FAO, 2013; Purcell, et al., 2013). From this analysis, it appears that the catches still increase in some regions, sometimes appear to stabilize, but this is often a bias due to the changes in species captured from high to lower value categories, or diminished in highly overexploited countries.

The sea cucumber resource has now attracted much attention, but it is still mostly not well managed. It appears that the statistics quality must be much improved, at the different levels. There are still much confusion between the live weights and the weights obtained from the various forms of processing. Another difficulty arises from countries having fisheries in two oceans (Atlantic and Pacific, for example for the latinoamerican region) and the data are not differentiated. As the fisheries are generally multispecific, the specific conversion values have to be evaluated for the species not previously captured; they have then to be adopted and used in international, regional and national instances.

The main markets statistics data are important to follow recent changes Hong Kong the main market is detailed here, but attention has to be paid to the others markets and their reciprocal exchanges, The most recent data for Hong Kong (2013-2014) are useful to show trends as the increase in number of exporting countries, but also need improvement in the categories changes and delimitation.

These sea cucumber resources need much better management practices, taking into account the socio-economic situations and the various actors (Purcell, et al., 2013). Some international and regional advances have appeared during the last decade, at the FAO initiative, in collaboration with other agencies and organizations. But during the same period the illegal fisheries have bloomed, their characteristics have been discussed to find the best ways to fight them (Conand, et al., 2015). As already presented by Eriksson, et al., (2015b) 'multi-level and multi-scale decision making is urgently needed to control and mitigate the effects of contagious exploitation'.

Mariculture had long been used in China and Japan for the temperate species Apostichopus japonicus (Lovatelli, et al. 2004; Yang, Hamel, Mercier, 2015). Mariculture then developed on the tropical sandfish Holothuria scabra in Madagascar and other countries in the Indo-Pacific and the interest is raising on several species (Purcell et al, 2012b; Brown \& Eddy, 2015). Several countries from the latinoamerican region (Ecuador, Nicaragua, Colombia) are presently conducting experiments on Isostichopus fuscus (see Lovatelli et al., 2004 and SPC Bêche de mer Bulletins). Mariculture is very important to the future conservation of the resources.

As large and abundant species in the benthic communities, the exploited holothurians play very important ecological roles in the bioturbation of the sediments where they live, in recycling nutrients by their nutrition, in being preyed (mostly as juveniles) thus transferring organic matter to higher trophic levels, and finally in enhancing biodiversity through the very large variety of symbionts and parasites they host (Eeckhaut, Parmentier, Becker, Gomez da Silva \& Jangoux, 2004; Purcell, et al., 2016).

\section{ACKNOWLEDGMENTS}

I thank FAO for the recent capture data and Stan Shea (Bloom/Hong Kong) for the Hong Kong market statistics. Institut Français d'Amérique Centrale and the organizers of 3rd Congreso Latinoamericano de Equinodermos (Costa Rica) are warmly thanked for invitation and financial support. The comments of S. Purcell, I. Eeckhaut and J.J. Alvarado have been very valuable to improve the manuscript. 


\section{RESUMEN}

Expansión de la pesca global de pepino de mar. Las pesquerías de pepino de mar se han expandido durante las últimas dos décadas, a un ritmo más rápido que la capacidad de gestión. La explotación ahora se califica como "en serie" y "contagiosa". Aquí presento las tendencias más recientes, según los últimos seis años de los datos de captura de la FAO. Hong Kong sigue siendo el mercado más importante para las importaciones y re-exportaciones de los productos transformados, principalmente el "trepang" seco (o bêche-de-mer), así como otros productos, lo que plantea dificultades para el análisis. Las capturas siguen aumentando, nuevos países desarrollan pesquerías de exportación, las especies clave cambiar y se comercializan nuevos productos.

Palabras clave: holoturio; trepang; bêche-de-mer; estadísticas; comercio; globalización; gestión.

\section{REFERENCES}

Anderson, S.C., Flemming, J.M., Watson, R., \& Lotze, H.K. (2011). Serial exploitation of global sea cucumber fisheries. Fish Fish, 12, 317-39.

Brown, N. P., \& Eddy, S.D. (2015). Echinoderm Aquaculture. Wiley ISBN 978-0-470-96038-7

Bruckner, A.W.(ed.) (2006) Proceedings of the CITES Workshop on the Conservation of Sea Cucumbers in the Families Holothuriidae and Stichopodidae NOAA Technical Memorandum NMFS-OPR-34, Silver Spring, MD, USA, 244 pp.

Conand, C. (1979). Bêche-de-mer in New Caledonia : weight loss and shrinkage during processing in three species of holothurians. S.P.C. Fisheries Newsletter, 19, 14-17.

Conand, C. (1989). Les Holothuries Aspidochirotes du lagon de Nouvelle-Calédonie : biologie, écologie et exploitation. Etudes et Thèses, O.R.S.T.O.M., Paris: 393 p.

Conand, C. (1990). The fishery resources of Pacific Island countries. Part 2: Holothurians. F.A.O. Fisheries Technical Paper, N. ${ }^{\circ} 272.2,143$ pp.

Conand, C. (1998) Overexploitation in the present world sea cucumber fisheries and perspectives in mariculture pp 449-454 in Echinoderms: San Francisco: Proceedings of the Ninth International Echinoderm Conference, San Francisco, California, USA, 5-9 August (eds R. Mooi and M. Telford). A.A. Balkema, Rotterdam.

Conand C. (2001). Overview of sea cucumbers fisheries over the last decade - what possibilities for a durable management ? Int. Echinoderms 2000, Barker (ed) Swets \& Zeitlinger: 339-344.
Conand, C. (2004). Present status of world sea cucumber resources and utilisation: an international overview pp. 13-23 in Lovatelli A., Conand C, Purcell S., Uthicke S., Hamel J.-F. \& Mercier A. eds. 2004. Advances in sea cucumber aquaculture and management. FAO Fisheries Technical Paper No. 463, 425 pp.

Conand, C. (2006) Sea cucumber biology: taxonomy; distribution; biology; conservation status pp 33-50 in Proceedings of the CITES Workshop on the Conservation of Sea Cucumbers in the Families Holothuriidae and Stichopodidae (ed. A. Bruckner), NOAA Technical Memorandum, NMFS-OPR 34, Silver Spring, MD, USA, 244 pp.

Conand, C. (2008). Population status, fisheries and trade of sea cucumbers in Africa and the Indian Ocean pp 143-193 in Sea Cucumbers: A Global Review of Fisheries and Trade, Vol. 516. (eds V. Toral-Granda, A. Lovatelli and M. Vasconcellos), FAO Fisheries and Aquaculture Technical Paper No. 516, FAO, Rome, 317 pp.

Conand, C. (2015). About lesser known beche-de-mer markets. S.P.C. Bêche-de-mer Information Bulletin, $35,58-59$.

Conand, C. (2016). Recent trends in world sea cucumber fisheries: captures, markets, management and the problem of the illegal. $3^{\circ} \mathrm{CLE}$ Congreso Latinoamericano de Equinodermos- Costa Rica (abstract).

Conand, C. \& Byrne, M. (1993). A review of recent developments in the world sea cucumber fisheries. Marine Fisheries Review, 55, 1-13.

Conand, C., \& Muthiga, N. (2007). Commercial sea cucumbers: a review for the Western Indian Ocean. WIOMSA Book Series No. 5, WIOMSA, Zanzibar, Tanzania, $67 \mathrm{pp}$.

Conand C., Polidoro, B., Mercier, A., Gamboa, R., Hamel, J.F., \& Purcell, S.W. (2014a). IUCN Red List workshop for sea cucumbers and its implications. S.P.C. Bêche-de-mer Information Bulletin, 34, 3-7.

Conand, C., Shea, S., \& To, A. (2014b). Beche-de-mer trade statistics in Hong Kong in 2012. S.P.C. Bêchede-mer Information Bulletin, 34, 43-46.

Conand, C., Eriksson, H., Leopold, M., Muthiga, N., Prescott, J., Purcell, S.W., \& Toral-Granda, M.V. (2015). Management of sea cucumber fisheries: the problem of illegal captures. WIOMSA 9th Scientific Symposium, 69 (abstract).

Eeckhaut, I., Parmentier, E., Becker, P., Gomez da Silva, S., \& Jangoux, M. (2004). Parasites and biotic diseases in field and cultivated sea cucumbers pp 311-325 in Advances in Sea Cucumber Aquaculture and Management. FAO Fisheries Technical Paper, 463, A. Lovatelli et al. (eds.), FAO, 425 pp. 
Eriksson, H., Österblom, H., Crona,,B., Troell, M., Andrew N., \& Folke, J. (2015a). Contagious exploitation of marine resources. Frontiers in Ecology and the Environment, 13(8), 435-440.

Eriksson, H., Conand, C., Lovatelli, A., Muthiga, N., \& Purcell, S.W. (2015b). Governance structures and sustainability in Indian Ocean sea cucumber fisheries. Marine Policy, 56, 16-22.

Fabinyi, M. (2016). Sustainable seafood consumption in China. Marine Policy, 74, 85-87.

FAO (2010). Putting into Practice an Ecosystem Approach to Managing Sea Cucumber Fisheries. Food and Agriculture Organization of the United Nations, Rome, 86 pp.

FAO (2012). Report on the FAO Workshop on Sea Cucumber Fisheries: An ecosystem approach to management in the Pacific (SCEAM Pacific 2011). FAO Report 1003 Rome, 44 pp.

FAO (2013). Report on the FAO Workshop on Sea Cucumber Fisheries: An ecosystem approach to management in the Indian Ocean (SCEAM Indian Ocean 2012). FAO Report 1038 Rome, 92 pp.

Flores, A., Lovatelli, A., Slater, M., \& Toral-Granda, V. (2016). International seminar on the exploitation and sustainable management of sea cucumber resources: lessons learned and recommendations for the State of Yucatan, Mexico Mérida City, Yucatan, Mexico. SPC Bêche-de-mer Information Bulletin, 36, 96-98.

Friedmann, K., Purcell, S.W., Bell, J., \& Hair, C. (2008) Sea cucumber fisheries: A manager's toolbox. ACIAR Monograph No. 135. Australian Centre for International Agricultural Research, Canberra. $32 \mathrm{p}$. http://www.aciar.gov.au/publication/mn135

Gomes, A.R., Freitas, A.C., Duarte, T.A.P., \& RochaSantos (2016). Echinoderms: A review of bioactive compounds with potential health effects, pp. 1-54 in Atta-ur-Rahman (Ed.), Studies in Natural Products Chemistry.

González-Wangüemert, M., Aydin, M., \& Conand, C. (2014). Assessment of sea cucumber populations in the Aegean Sea (Turkey): First insights to sustainable management of new fisheries. Ocean \& Coastal Management, 92, 87-94.

González-Wangüemert, M., Valente, S., Henriques, F., Domínguez-Godino, J., \& Serrão, E. (2016). Setting preliminary biometric baselines for new target sea cucumbers species of the NE Atlantic and Mediterranean fisheries. Fisheries Research, 179, 57-66.

Honey-Escandon, M., Arreguín-Espinosa, R., Solís-Marín, F.A., \& Samyn, Y. (2015). Biological and taxonomic perspective of triterpenoid glycosides of sea cucumbers of the family Holothuriidae (Echinodermata,
Holothuroidea). Comparative Biochemistry and Physiology, Part B 180, 16-39.

IUCN http://www.iucnredlist.org/documents/RedListGuidelines.pdf

Jaquemet, S., \& Conand, C. (1999). The beche-de-mer trade in 1995-96 and an assessment of exchanges between the main world markets. S.P.C.Bêche-de-mer Information Bulletin, 12, 11-14.

Lovatelli, A., Conand, C., Purcell, S., Uthicke, S., Hamel, J.-F., \& Mercier, A. (2004). Advances in Sea Cucumber Aquaculture and Management. FAO Fisheries Technical Paper No. 463, FAO, 425 pp.

Muthiga N.A., \& Conand C. (2014). Sea cucumbers, a Poorly Understood but Important Coastal Resource: A Regional Analysis to Improve Management. WIOMSA Book Series No. 14. viii, 74 pp.

Prescott, J., Zhou, S., \& Prasetyo, A.P. (2015). Soft bodies make estimation hard:correlations among body dimensions and weights of multiple species of sea cucumbers. Marine and Freshwater Research. 66. http://dx.doi.org/10.1071/MF14146

Purcell, S.W. (2010). Managing Sea Cucumber Fisheries with an Ecosystem Approach. FAO Fisheries and Aquaculture Technical Paper No. 520, FAO.

Purcell, S.W. (2014a). Processing sea cucumbers into beche-de-mer: A manual for Pacific Island fishers. Southern Cross University, Lismore, and the Secretariat of the Pacific Community, Noumea. 44 pp.

Purcell, S.W. (2014b). Value, Market Preferences and Trade of Beche-De-Mer from Pacific Island Sea Cucumbers. PLoS ONE, 9(4): e95075. doi:10.1371/ journal.pone.0095075

Purcell, S.W., Gossuin, H., \& Agudo, N.S. (2009). Changes in weight and length of sea cucumbers during conversion to processed beche-de-mer: Filling gaps for some exploited tropical species. SPC Bêche-de-mer Information Bulletin, 29, 3-6.

Purcell, S.W., Samyn, Y., \& Conand, C. (2012). Commercially Important Sea Cucumbers of the World. FAO, $150 \mathrm{pp}$.

Purcell, S.W., Hair, C., \& Mills, D. (2012). Sea cucumber culture, farming and sea ranching in the tropics: progress, problems and opportunities. Aquaculture, 368-369, 68-81.

Purcell, S. W., Mercier, A., Conand, C., Hamel, J. F., ToralGranda, M. V., Lovatelli, A., \& Uthicke, S. (2013). Sea cucumber fisheries: global analysis of stocks, management measures and drivers of overfishing. Fish and Fisheries, 14(1), 34-59.

Purcell, S.W., Polidoro, B.A., Hamel, J.F., Gamboa, R. U., \& Mercier, A. (2014). The cost of being valuable: 
predictors of extinction risk in marine invertebrates exploited as luxury seafood. Proceedings of the Royal Society B: Biological Sciences, 281, 2013-3296.

Purcell, S.W., Ngaluafe, P., Aram, K.T., \& Lalavanua W. (2016). Variation in postharvest processing of sea cucumbers by fishers and commercial processors on three Pacific Islands countries. SPC Beche-de-mer Information Bulletin, 36: 58-66.

Purcell, S.W., Conand, C., Uthicke, S., \& Byrne, M (2016). Ecological roles of exploited sea cucumbers. Oceanography and Marine Biology: An Annual Review, 54, 367-386.
To, A.W.L. \& Shea, S.K.H. (2012). Patterns and dynamics of beche-de-mer trade in Hong Kong and mainland China: implications for monitoring and management. TRAFFIC Bull, 24: 65-75.

Toral-Granda, V., Lovatelli, A. \& Vasconcellos, M. (2008). Sea Cucumbers: A Global Review of Fisheries and Trade. FAO Fisheries and Aquaculture Technical Paper 516. FAO, 317 pp.

Yang, H., Hamel, J.F. \& Mercier, A. (2015). The Sea Cucumber Apostichopus japonicus History, Biology and Aquaculture. Elsevier. 